\title{
The east coast districts are the possible epicenter of severe dengue in Sabah
}

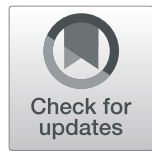

Narinderjeet Kaur', Syed Sharizman Syed Abdul Rahim', Joel Judson Jaimin², Jiloris Julian Frederick Dony², Koay Teng Khoon ${ }^{3}$ and Kamruddin Ahmed ${ }^{4,5^{*}}$ (D)

\begin{abstract}
Background: Malaysia recorded the highest number of dengue cases between 2014 and 2017. There are 13 states and three federal territories in Malaysia, and each area varies in their prevalence of dengue. Sabah is one of the states situated in Borneo, Malaysia. Although dengue has been increasing for the last several years, no study was being done to understand the burden and serotype distribution of the dengue virus (DENV) in Sabah. Therefore, the present study was carried out to understand the epidemiology of the dengue infection and the factors responsible for severe dengue in Sabah.
\end{abstract}

Methods: Data on dengue infection were extracted from the dengue database of the state of Sabah from 2013 through 2018. DENV NS-1-positive serum samples from multiple sites throughout Sabah were sent to the state public health laboratory, Kota Kinabalu Public Health Laboratory, for serotype determination. The analysis of factors associated with severe dengue was determined from the data of 2018 only.

Results: In 2013, there were 724 dengue cases; however, from 2014, dengue cases increased exponentially and resulted in 3423 cases in 2018. Increasing dengue cases also led to increased dengue mortality. The number of dengue deaths in 2013 was only five which then gradually increased, and in 2018, 29 patients died. This is an increase of 580\% from 2013 to 2018. Deaths were considerably more in the districts of the east coast of Sabah compared with districts in the west coast. During the study period, all DENV serotypes could be identified as serotypes circulating in Sabah. In 2018, the predominant serotype was DENV-3. The monthly peak of dengue infection varied in different years. In the logistic regression analysis, it was identified that children were 6.5 times, patients infected with mixed serotype of DENV were 13 times, and cases from the districts of the east coast were 5.2 times more likely to develop severe dengue.

Conclusions: An increasing trend of dengue infection has been observed in Sabah. The burden of dengue, severe dengue, and mortality was noted especially in the districts of the east coast of Sabah. Severe dengue was most likely developed in children, cases from the east coast, and patients infected with mixed serotype of DENV.

Keywords: Dengue, Severe dengue, Sabah, Serotype, Genotype

\footnotetext{
* Correspondence: ahmed@ums.edu.my

${ }^{4}$ Borneo Medical and Health Research Centre, Faculty of Medicine and Health

Sciences, Universiti Malaysia Sabah, 88400 Kota Kinabalu, Sabah, Malaysia

${ }^{5}$ Department of Pathobiology and Medical Diagnostics, Faculty of Medicine

and Health Sciences, Universiti Malaysia Sabah, Jalan UMS, 88400 Kota

Kinabalu, Sabah, Malaysia

Full list of author information is available at the end of the article
}

\section{$\triangle B M C$}

(c) The Author(s). 2020 Open Access This article is licensed under a Creative Commons Attribution 4.0 International License, which permits use, sharing, adaptation, distribution and reproduction in any medium or format, as long as you give appropriate credit to the original author(s) and the source, provide a link to the Creative Commons licence, and indicate if changes were made. The images or other third party material in this article are included in the article's Creative Commons licence, unless indicated otherwise in a credit line to the material. If material is not included in the article's Creative Commons licence and your intended use is not permitted by statutory regulation or exceeds the permitted use, you will need to obtain permission directly from the copyright holder. To view a copy of this licence, visit http://creativecommons.org/licenses/by/4.0/ The Creative Commons Public Domain Dedication waiver (http://creativecommons.org/publicdomain/zero/1.0/) applies to the data made available in this article, unless otherwise stated in a credit line to the data. 


\section{Background}

Dengue fever is a viral infection that is transmitted to humans by the bite of infected Aedes mosquitoes. Globally, every year, an estimated 390 million people are infected with dengue [1]. About 75\% of these occur in Southeast Asia and Western Pacific regions [2]. Before 1970, only nine countries were endemic for dengue; however, now, 120 countries are affected indicating dengue is spreading at an alarming pace [3]. It is thought that global warming might have increased the survival and/or migration of mosquitoes into previously nonendemic areas outside the tropics. Globalization, urbanization, trade, and travels [4] might have also contributed to the spread of dengue.

Dengue infection is generally mild [5], but in 5 to $20 \%$ of cases, it may progress to severe dengue depending on the immunity of the person $[4,5]$. Severe dengue is manifested by plasma leakage, hemorrhage and organ dysfunction, and even death [6]. Early supportive care can reduce mortality in severe dengue cases; however, there is no reliable method to predict progression to severe dengue. The warning signs for severe dengue have a low positive predictive value and develop only later in the disease where it might already be too late [5].

Dengue virus (DENV) is a positive-sense, single-stranded RNA virus found in the genus Flaviviridae. It is classified into four main serotypes (DENV-1, DENV-2, DENV-3, and DENV-4), which are distinct genetically but cause similar disease features. Infection with one of the serotypes is believed to produce durable, life-long, homotypic immunity against the particular serotype; however, it only generates partial and transient cross-protection against the other three serotypes. This allows for sequential dengue infections with other serotypes in the same individual [1].

Recently, the Asia Pacific region has been burdened with an increased threat of dengue. Thailand is experiencing the largest dengue epidemic in more than 20 years [7]. The escalating cases have also been observed in Bangladesh [8]. In the Philippines [9], Laos [10], and Myanmar [11], similar patterns of increased cases, severity, and mortality were observed. A study in Sri Lanka identified that the increasing number of dengue cases and the changes in the virulence of the virus were due to the shifting of genotypes and subtypes of the circulating DENVs [12]. This diversity amongst genotypes and serotypes is one of the major challenges in the development of tetravalent vaccines [13].

Dengue is endemic in Malaysia, and the first case was detected back in 1902 [6]. It is prevalent throughout the year although peak transmission occurs in the late monsoon season. Malaysia recorded the highest number of dengue cases through 2014 and 2016 [6], where 2015 observed a peak with 120,836 cases and 336 deaths, which might translate into one death daily [6]. Although the cause of this increase is not known, this might be due to improved notification rates as well as access to better diagnostic tools. However, the possible reasons for the increase in mortality remain obscure leading us to wonder whether the variation in serotype is the contributing factor to the increasing cases and mortality [14].

A similar pattern of increasing trend of dengue infection is also observed in Sabah which needs immediate measures to assess this regional issue. However, data on the serotype distribution in Sabah is still lacking [15]. This requires a comprehensive study on the epidemiology and circulating serotypes in Sabah to determine whether they are associated with increased virulence or whether other associated factors are responsible. The aim of this study is to determine the burden of dengue as well as to identify the circulating serotypes of DENV in Sabah during the past 6 years along with the temporal patterns and other factors that are associated with severe dengue. The information obtained from this study will be useful to formulate a policy for dengue control in this state.

\section{Methods}

Study area

The study was performed in Sabah, Malaysia, situated in the northern part of Borneo island. The size of the state is $73,904 \mathrm{~km}^{2}$ with a population of 3.9 million [16]. Sabah has land borders with the Malaysian state of Sarawak to the southwest and Indonesia's Kalimantan region to the south. It also shares maritime borders with Vietnam to the west and the Philippines to the north and east. Sabah has abundant natural resources, and its economy is strongly export oriented. Its primary exports include oil, gas, timber, and palm oil. The other major industries are agriculture and ecotourism. The capital of Sabah is Kota Kinabalu, and the state is divided into Kudat, Interior, Sandakan, Tawau, and west coast divisions with a total of 23 districts.

\section{Case definitions}

This paper followed WHO's 2009 criteria for case definition of dengue fever and severe dengue [17]. Dengue is defined as a combination of two or more clinical findings in a person with fever. The clinical findings include nausea, vomiting, rash, aches and pains, a positive tourniquet test, leukopenia, and the following warning signs: abdominal pain or tenderness, persistent vomiting, clinical fluid accumulation, mucosal bleeding, lethargy, restlessness, and liver enlargement. The presence of a warning sign may predict severe dengue in a patient.

Severe dengue is defined as dengue with symptoms of either severe plasma leakage leading to shock or fluid accumulation with respiratory distress, severe bleeding or severe organ impairment such as elevated transaminases $\geq 1000 \mathrm{IU} / \mathrm{L}$, impaired consciousness, or heart impairment. 


\section{Data preparation}

Data on dengue cases and death from 2013 through 2018 were extracted from the database of dengue infection from Sabah State Health Department. Dengue NS-1 positive serum samples were sent to Kota Kinabalu Public Health Laboratory from various sites throughout Sabah for serotype determination under the virus serotype surveillance program as well as for diagnostic purposes. Dengue NS-1 assay was performed according to the manufacturer's instructions using serum specimens. The rapid diagnostic test had a control line and a test line. The appearance of the test and control lines after a specified migration time (15-30 $\mathrm{min})$ indicated a positive result. The appearance of the control line alone indicated a negative result. The technicians carrying out the evaluation of the test articles were blind to the DENV infection status of the panel of serum samples. At present, samples were obtained from 20 hospitals and 17 health clinics throughout Sabah (Fig. 1). Although Labuan is a federal territory, i.e. separate from the state of Sabah, but because of its geographical proximity to Sabah, samples are sent to Kota Kinabalu Public Health Laboratory for testing. Analysis of severe dengue was conducted for the samples obtained in 2018 only because severe dengue was recorded as a separate variable in the database as of 2018. Descriptive statistics, as well as multiple logistic regression, were performed to analyze the data using IBM SPSS Statistics software package (International Business Machines Corporation, Armonk, NY, USA).

\section{Serotyping}

Serotyping was done at Kota Kinabalu Public Health Laboratory. Total viral RNA was extracted from serum samples using QIAamp Viral RNA Mini Kit (Qiagen Company, Hilden, Germany) according to the manufacturer's instructions. All the serotypes of DENV were determined by real-time PCR using $a b T E S$ Den 4 (AITbiotech, Singapore) according to the manufacturer's instructions using exacted RNA.

\section{Results}

\section{Dengue burden}

\section{Prevalence of dengue in Sabah}

In 2013, there were 724 dengue cases; however, from 2014, dengue cases increased exponentially to 1456 cases, which is almost double the number of cases from the previous year (Fig. 2). In 2015, the cases doubled even further to 2904. In 2016, the number of cases peaked at 3668 cases, and there was a brief decrease in cases to 2560 in 2017. These numbers did not stay low but increased to 3423 cases in 2018.

Unfortunately, increasing dengue cases have also led to increased dengue mortality (Fig. 2). The number of dengue deaths reported was 5 and 6 in 2013 and 2014, respectively. In 2015 , the number of deaths increased to

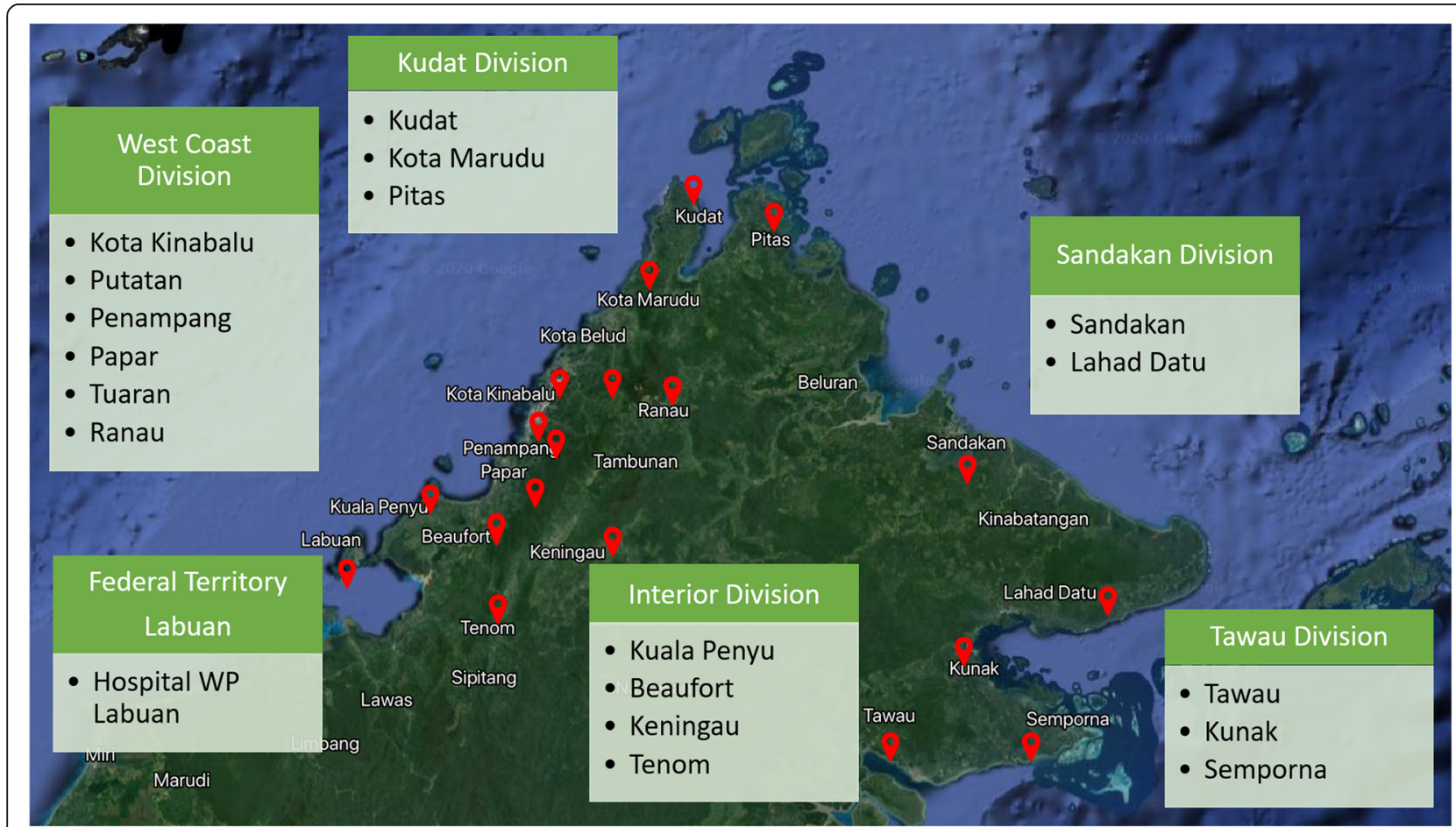

Fig. 1 Map of Sabah showing the sentinel sites in different districts 


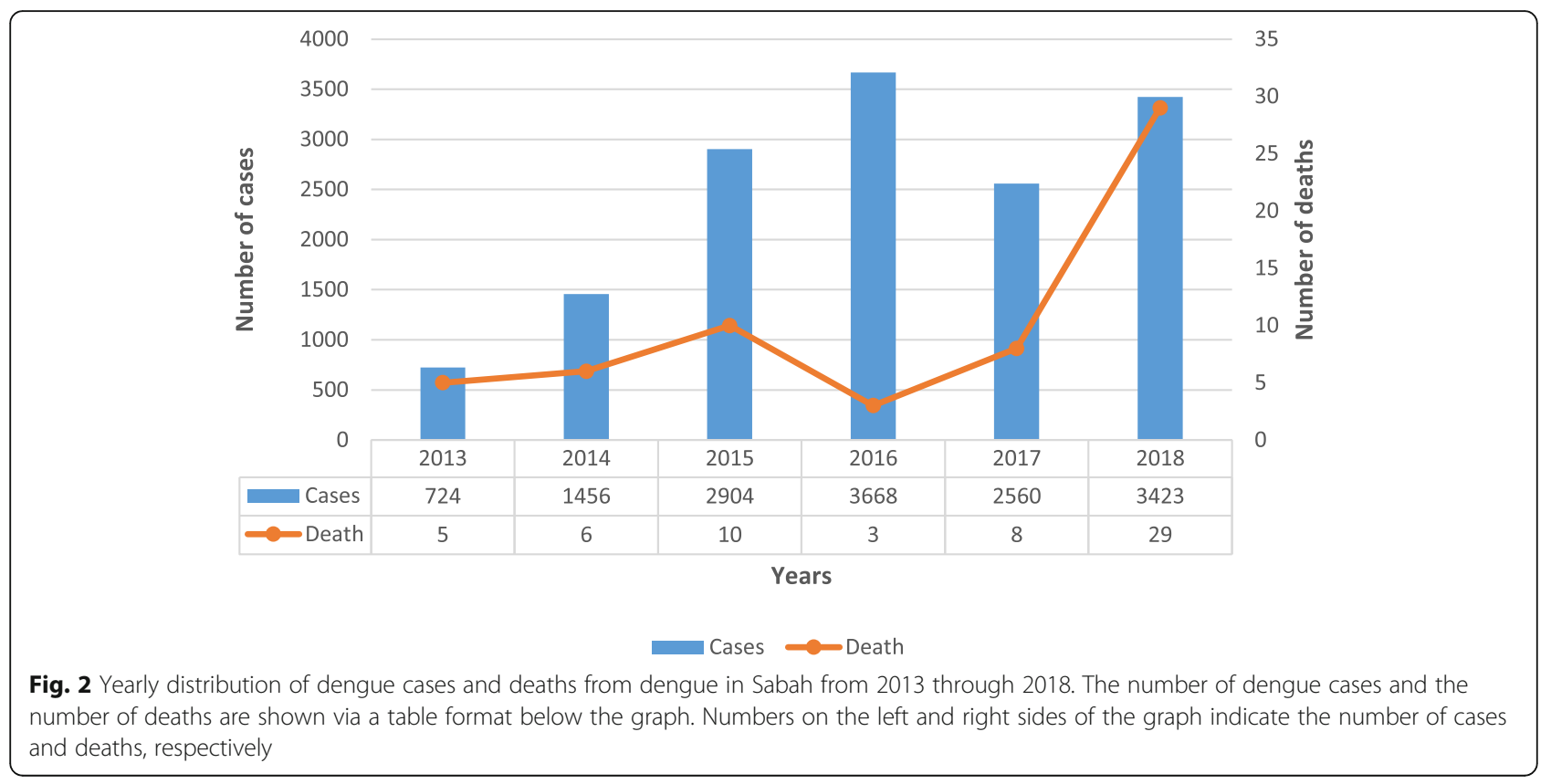

10, but in 2016, it reduced to 3 deaths. This reduction did not last long as the numbers increased to 8 in 2017. The most shocking figure was reported in 2018 with a staggering total of 29 deaths reported. This shows an increase of 362\% in 1 year (from 2017 to 2018).

\section{Dengue deaths based on each district}

The deaths based on districts are described in Table 1. From 2013 to 2017, the total death in Sabah ranged from 3 to 10; however, in 2018, it was 29. During these 6 years, the total death in Kota Kinabalu was 7; however, the total deaths in each district in the west coast was between 0 and 2 . In the east coast districts, the total number of deaths was highest in Tawau with 10 deaths, followed by Semporna with another 10 deaths, and subsequently Lahad Datu with 8 deaths, followed by Sandakan which also reported 8 deaths.

\section{Dengue cases from multiple sites}

A total of 3224 samples were obtained from all the multiple sites in Sabah (Table 2). In 2013, 2014, 2015, 2016, 2017, and 2018, a total of 182, 198, 379, 150, 964, and 1351 samples were collected, respectively. Age distribution of dengue was available for 2018 only. The majority of dengue cases were adults (603/ 1351, 44.6\%), followed by adolescents (405/1351, $30.0 \%$ ), and children (343/1351, 25.4\%). According to Najri et al. [15], for age categories, adults were defined as those 20 years and above, adolescents were 10-19 years old, and children were under 19 years old.
Among the sites, the highest number of samples was from the Queen Elizabeth Hospital situated in the Kota Kinabalu district as it is the largest tertiary care state hospital and has the largest population coverage in Sabah.

Table 1 Number of dengue deaths in each district in Sabah from 2013 through 2018

\begin{tabular}{|c|c|c|c|c|c|c|c|}
\hline District & 2013 & 2014 & 2015 & 2016 & 2017 & 2018 & Total \\
\hline Kota Kinabalu & 1 & 2 & 1 & 0 & 1 & 2 & 7 \\
\hline Penampang & 0 & 0 & 1 & 0 & 1 & 0 & 2 \\
\hline Papar & 0 & 0 & 0 & 0 & 0 & 1 & 1 \\
\hline Lahad Datu & 0 & 1 & 0 & 1 & 1 & 5 & 8 \\
\hline Tawau & 2 & 1 & 1 & 0 & 1 & 5 & 10 \\
\hline Beaufort & 0 & 0 & 0 & 0 & 0 & 0 & 0 \\
\hline Semporna & 0 & 0 & 3 & 0 & 2 & 5 & 10 \\
\hline Sandakan & 1 & 0 & 3 & 1 & 0 & 3 & 8 \\
\hline Kudat & 0 & 0 & 0 & 0 & 0 & 2 & 2 \\
\hline Pitas & 0 & 0 & 0 & 0 & 0 & 0 & 0 \\
\hline Beluran & 0 & 1 & 0 & 0 & 0 & 0 & 1 \\
\hline Kunak & 0 & 0 & 0 & 0 & 1 & 5 & 6 \\
\hline Kota Marudu & 1 & 0 & 0 & 0 & 0 & 0 & 1 \\
\hline Kinabatangan & 0 & 0 & 0 & 0 & 0 & 0 & 0 \\
\hline Sipitang & 0 & 0 & 0 & 0 & 0 & 0 & 0 \\
\hline Putatan & 0 & 1 & 1 & 0 & 0 & 0 & 2 \\
\hline Ranau & 0 & 0 & 0 & 1 & 0 & 0 & 1 \\
\hline Tuaran & 0 & 0 & 0 & 0 & 1 & 1 & 2 \\
\hline Total & 5 & 6 & 10 & 3 & 8 & 29 & 61 \\
\hline
\end{tabular}


Table 2 Number of samples collected from dengue patients from multiple sites in Sabah from 2013 through 2018

\begin{tabular}{|c|c|c|c|c|c|c|c|c|c|}
\hline Division & District & Sentinel hospitals and clinics & 2013 & 2014 & 2015 & 2016 & 2017 & 2018 & Total \\
\hline \multirow[t]{15}{*}{ West coast division } & \multirow[t]{8}{*}{ Kota Kinabalu } & Queen Elizabeth Hospital & \multirow[t]{5}{*}{139} & \multirow[t]{2}{*}{129} & \multirow[t]{2}{*}{209} & 30 & 440 & 307 & 1250 \\
\hline & & Queen Elizabeth Hospital 2 & & & & 1 & 3 & 11 & 15 \\
\hline & & Sabah Women and Children Hospital & & \multirow[t]{3}{*}{2} & \multirow[t]{3}{*}{1} & \multirow[t]{3}{*}{12} & 26 & \multirow[t]{3}{*}{135} & 176 \\
\hline & & Klinik Kesihatan Ibu Anak Jalan Kebajikan & & & & & 1 & & 1 \\
\hline & & Klinik Kesihatan Likas & & & & & 1 & & 1 \\
\hline & & Klinik Kesihatan Luyang & \multirow[t]{13}{*}{41} & 41 & 5 & 1 & 76 & 67 & 231 \\
\hline & & Klink Kesihatan Menggatal & & 1 & & & & & 1 \\
\hline & & Klinik Kesihatan Telipok & & & 4 & 5 & 1 & & 10 \\
\hline & Putatan & Klinik Kesihatan Putatan & & 7 & 63 & 8 & & 8 & 86 \\
\hline & Penampnag & Klink Kesihantan Penampang & & & 1 & & & & 1 \\
\hline & Papar & Hospital Papar & & & & & & 3 & 3 \\
\hline & \multirow[t]{3}{*}{ Tuaran } & Hospital Tuaran & & & & & 122 & 49 & 171 \\
\hline & & Klinik Kesihatan Tamparuli & & 3 & 3 & 1 & 6 & 1 & 14 \\
\hline & & Klinik Kesihatan Kiulu & & & 1 & & & & 1 \\
\hline & Ranau & Hospital Ranau & & & 2 & & 1 & 1 & 4 \\
\hline \multirow[t]{4}{*}{ Kudat division } & Kudat & Hospital Kudat & & 1 & 4 & 4 & 54 & 28 & 91 \\
\hline & \multirow[t]{2}{*}{ Kota Marudu } & Hospital Kota Merudu & & 2 & & & & 1 & 3 \\
\hline & & Klinik Kesihatan Tandek & & & 1 & & & & 1 \\
\hline & Pitas & Hospital Pitas & 2 & 5 & & & & 2 & 9 \\
\hline \multirow[t]{5}{*}{ Interior division } & Kuala Penyu & Hospital Kuala Penyu & & & 2 & & & & 2 \\
\hline & Beaufort & Hospital Beaufort & & 3 & 2 & 2 & & & 7 \\
\hline & \multirow[t]{2}{*}{ Keningau } & Hospital Keningau & & & 1 & & 3 & 2 & 6 \\
\hline & & Klinik Kesihatan Bingkor & & & & & & 2 & 2 \\
\hline & Tenom & Hospital Tenom & & & & & 1 & & 1 \\
\hline \multirow[t]{6}{*}{ Sandakan division } & \multirow[t]{2}{*}{ Sandakan } & Hospital Duchess of Kent & & & 67 & 73 & 18 & 12 & 170 \\
\hline & & Klinik Kesihatn Sandakan & & & 4 & & & & 4 \\
\hline & \multirow[t]{4}{*}{ Lahad Datu } & Hospital Lahad Datu & & 3 & & & 27 & 121 & 151 \\
\hline & & Klinik Kesihatan Lahad Datu & & & 3 & & & 10 & 13 \\
\hline & & Klinik Kesihatan Tungku & & & & & & 12 & 12 \\
\hline & & Klinik Kesihatan Felda Sahabat & & & & & & 1 & 1 \\
\hline \multirow[t]{4}{*}{ Tawau division } & \multirow[t]{2}{*}{ Tawau } & Hospital Tawau & & 1 & 5 & 1 & 149 & 384 & 540 \\
\hline & & Klinik Kesihatan Tawau & & & & & & 24 & 24 \\
\hline & Kunak & Hospital Kunak & & & & & & 56 & 56 \\
\hline & Semporna & Hospital Semporna & & & 1 & 12 & 2 & 84 & 99 \\
\hline Federal territory Labuan & & Hospital WP Labuan & & & & & 33 & 30 & 63 \\
\hline Total each year & & & 182 & 198 & 379 & 150 & 964 & 1351 & 3224 \\
\hline
\end{tabular}

\section{Severe cases in multiple sites}

No severe case was detected in 2013 (Table 3). In 2014, three severe cases were detected out of the 198 cases in the health centers which is $1.5 \%$. During 2015, 2016, and 2017, $2.1 \%$ (8/379), $2 \%$ (3/150), and $0.5 \%$ (5/964) of the total cases, respectively, were severe. In 2018, 10.8\% $(146 / 1351)$ of the cases were severe. During the whole study period, district wise, most of the severe cases were found in Tawau (110), followed by Lahad Datu (17),
Kota Kinabalu (17), Sandakan (11), Semporna (9), and Labuan (1).

\section{Circulating serotype in Sabah}

In Sabah, the predominant circulating serotype in 2013 was DENV-4. In 2014, DENV-1 was predominant. Interestingly, in 2015, DENV-2 was dominant. Then, from 2016 up to 2018, DENV-3 became dominant (Fig. 3). Mixed serotypes ranged from 0 to $1 \%$ and abruptly 
Table 3 Distribution of severe dengue cases in different districts of Sabah

\begin{tabular}{|c|c|c|c|}
\hline Year & Number of severe cases & Number of case and name of district & Total \\
\hline 2013 & 0 & - & 182 \\
\hline 2014 & 3 & $\begin{array}{l}\text { 1-Lahad Datu } \\
\text { 1-Tawau } \\
\text { 1-Luyang (Kota Kinabalu) }\end{array}$ & 198 \\
\hline 2015 & 8 & $\begin{array}{l}\text { 1-Tawau } \\
\text { 3-Semporna } \\
\text { 4-Sandakan }\end{array}$ & 379 \\
\hline 2016 & 3 & $\begin{array}{l}\text { 1-Semporna } \\
\text { 2-Sandakan }\end{array}$ & 150 \\
\hline 2017 & 5 & $\begin{array}{l}\text { 2-Tawau } \\
\text { 1-Labuan } \\
\text { 1-Women and Children's Hospital (Kota Kinabalu) } \\
\text { 1-Queen Elizabeth Hospital (Kota Kinabalu) }\end{array}$ & 964 \\
\hline 2018 & 146 & $\begin{array}{l}\text { 106-Tawau } \\
\text { 16-Lahad Datu } \\
\text { 5-Semporna } \\
\text { 5-Sandakan } \\
\text { 7-Women and Children's Hospital (Kota Kinabalu) } \\
\text { 7-Queen Elizabeth Hospital (Kota Kinabalu) }\end{array}$ & 1351 \\
\hline
\end{tabular}

increased to $5 \%$ in 2015. It then increased further to 9.3\% in 2016, and from 2017 came back down to $0.1 \%$. Undetermined serotype was between 14.5 and $33.3 \%$. In 2018, a total of 17 samples were designated as containing mixed serotypes, two different serotypes present concurrently in one sample. Eight samples contained the combination of DENV 2 and DENV 3, seven samples contained the combination DENV 1 and DENV 3, and two samples contained the combination of DENV 1 and DENV 2.

\section{Monthly distribution of dengue serotype}

In 2013, one peak was evident in February, whereas in 2014, two peaks were detected in May and July (Fig. 4).

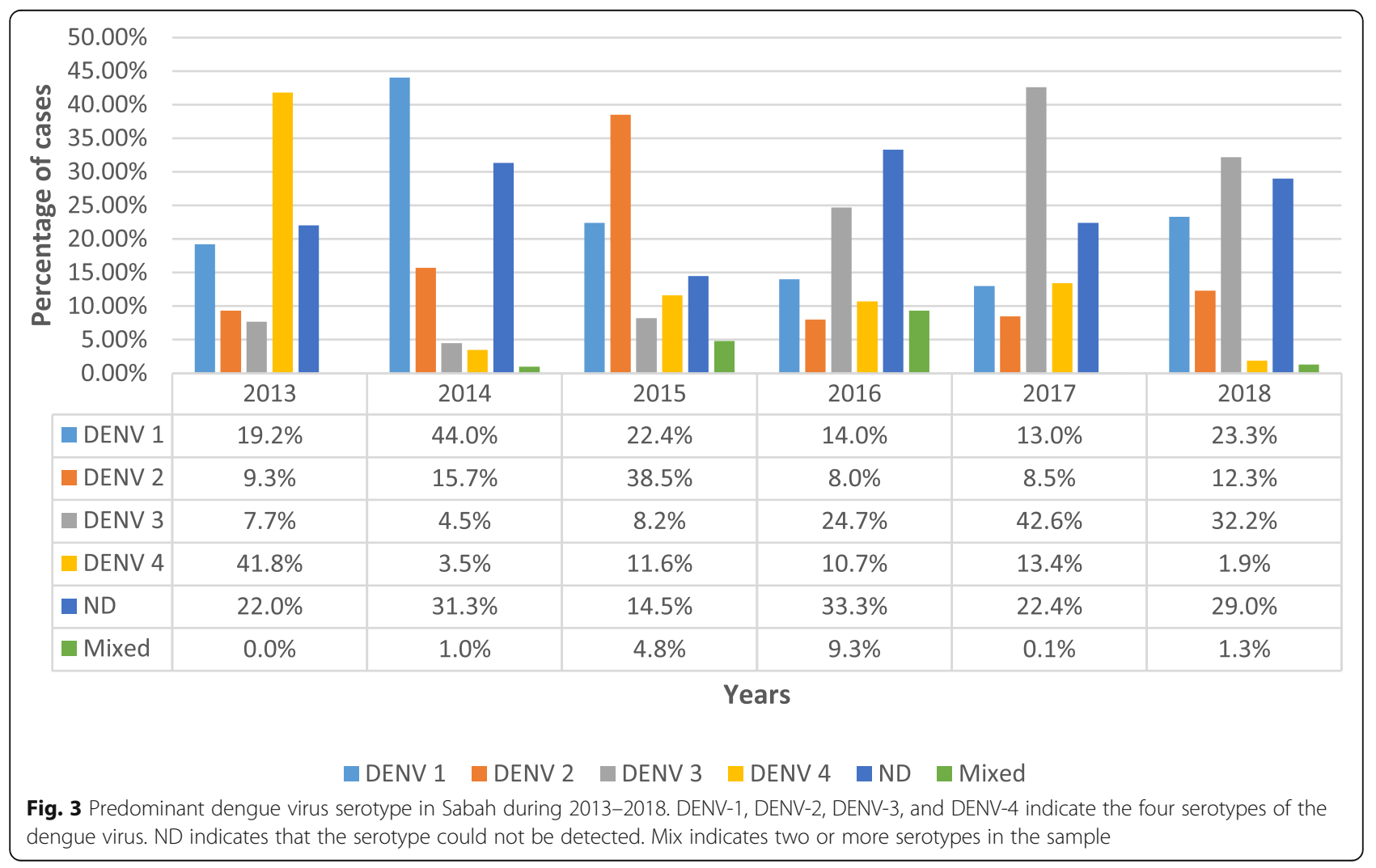



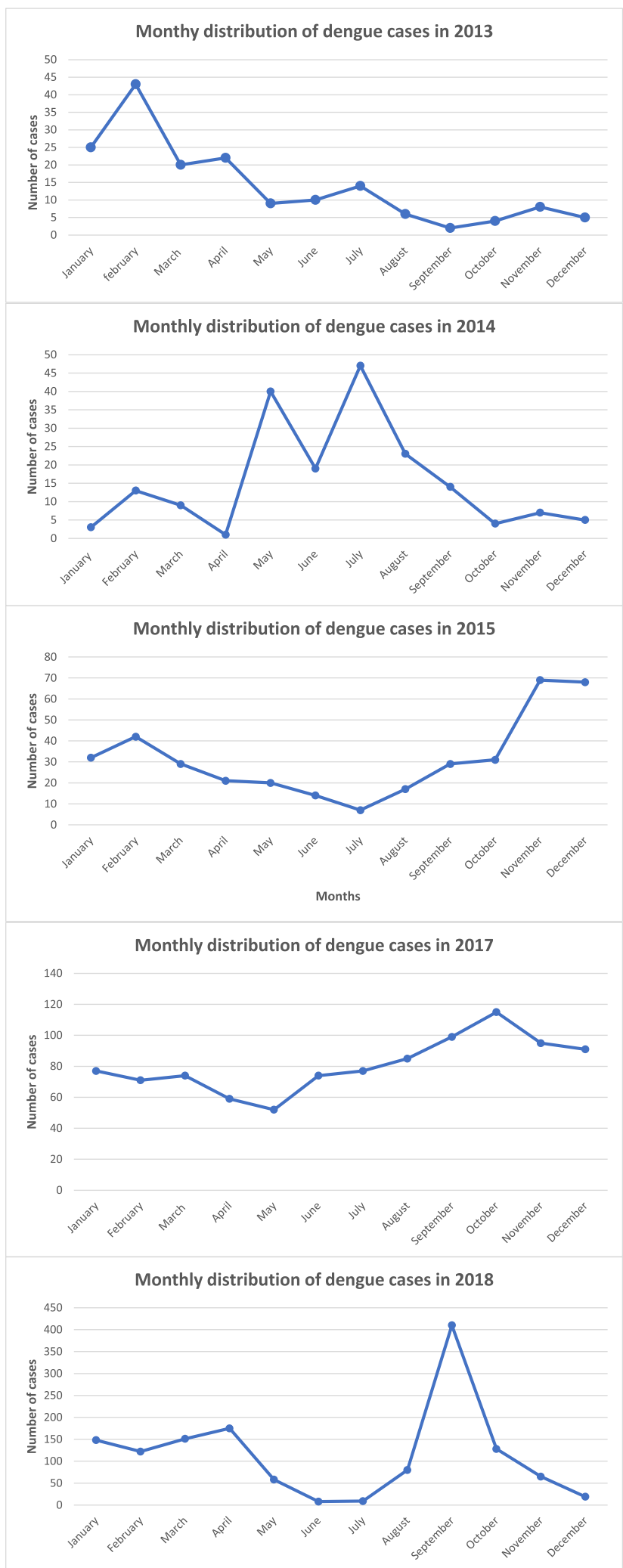

Fig. 4 Monthly distribution of positive dengue virus cases in 2013, 2014, 2015, 2017, and 2018 
In 2015, again two peaks were noted, one in February and the other in November. In 2016, dengue data were not fully available and not included in this study. In 2017, the peak was in October. In 2018, again two peaks were noted in April and September.

\section{Associating factors for severe dengue}

Our logistic regression analysis revealed that children were 6.5 times (95\% CI 3.45-12.27, $p=0.00$ ) more likely to develop severe dengue when compared to adults (Table 4). Patients who were infected with the mixed DENV serotypes were 13 times more likely to develop severe dengue (95\% CI 3.67-46.01, $p=0.00$ ), patients infected with the DENV-1 serotype were 1.8 times more likely to develop severe dengue (95\% CI 1.21-2.88, $p=$ $0.00)$, compared with those infected with DENV-2, 3, and 4 infections. It was also identified that cases reported from the eastern part of Sabah (Sandakan and Tawau divisions) were 5.2 times more likely to develop severe dengue (95\% CI 2.74-9.79, $p=0.00$ ) compared with cases from other parts of Sabah.

\section{Discussion}

Although Sabah dengue cases are lower compared to other states in Peninsular Malaysia [18], this situation is changing, and an increasing trend of dengue infection has been observed. The highest number of dengue cases was reported at Queen Elizabeth Hospital, Kota Kinabalu. This can be attributed to the fact that it is the largest tertiary care state hospital and has the largest population.

However, regardless of that fact, an increasing trend of dengue can be observed in other hospitals as well, for example, from Hospital Tawau, Hospital Lahad Datu, and Hospital Semporna. These results further solidify the fact that dengue cases in Sabah are indeed increasing. The number of cases from Sabah Women and Children's Hospital is also increasing yearly. This is a tertiary care hospital mainly for children and situated in Kota Kinabalu. This increasing number is worrying as it indicates more children are suffering from dengue. A study conducted showed that $67 \%$ of the children in Southeast Asia are vulnerable to dengue [19]. It supports our results that children suffer more from severe dengue than other age groups.
It has also been identified that the lifetime risk of getting dengue is more than $90 \%$ in Malaysia [19]. Those infected require immediate medical consultation. This can pose as a serious economic burden as the household cost of a single dengue case in Malaysia is about US\$ 365 (MYR 1460) [20]. At the country level, the economic cost is more. It was estimated that about US\$ 73.5 million (MYR 294 million) is spent yearly on dengue vector control only [21]. This amount constitutes $0.03 \%$ of the country's GDP and $1.2 \%$ of the total government funding for health care in Malaysia (MYR 24 billion) [21]. If the trend of dengue increases, then it will increase the cost proportionately.

The results obtained from this study showed that dengue is prevalent in Sabah throughout the year; however, the peak varies from year to year. The climate in Sabah is considered equatorial; however, the climatic conditions are different in areas such as the highlands when compared to coastal areas. Although the hottest time of the year is between May and September, the temperature difference between this time and the rest of the year is very minimal. Only two seasons are distinguishable, which are rainy and dry. Although rain is a possibility year-round, the rainy season in most of Sabah is from October to February. The rest of the year is considered the dry season. However, the west coast of Sabah starts to have a higher rainfall from May until the end of the year, while the east coast is relatively stable during June and July with afternoon showers. Therefore, more study is needed to determine whether the seasonal variation of dengue differs from place to place.

Seasonal appearance of mosquitoes is one of the important factors for dengue transmission. A study in Singapore showed that infected Aedes aegypti appeared much earlier, compared to Aedes albopictus, approximately as early as 6 weeks before the occurrence of an outbreak [22]. Furthermore, all outbreaks reported from Taiwan for two decades showed that A. aegypti was more critical to the transmission of dengue viruses than was A. albopictus [23]. Perhaps, dengue outbreaks can only occur when $A$. aegypti exists or it is the predominant species [24].

Table 4 The regression coefficient was determined to find the effects of a predictor variable on the severity of dengue cases. Since the $P$ values are all $<0.05$, therefore, the variables are significant to the model. Wald statistics identified that each factor is significant and contributes to the prediction model

\begin{tabular}{lllll}
\hline Variable & Regression coefficient & Adjusted odds ratio (95\% confidence interval) & Wald statistics & $P$ value \\
\hline Age (0-9 years) & 1.87 & $6.5(3.45-12.27)$ & 33.36 & $<0.001$ \\
Mixed dengue virus serotype & 2.56 & $13(3.67-46.01)$ & 15.78 & 7.88 \\
Dengue virus serotype-1 & 0.62 & $1.8(1.21-2.88)$ & 0.001 \\
Districts of east coast & 1.65 & $5.2(2.74-9.79)$ & 25.64 & $<.005$ \\
\hline
\end{tabular}


But generally speaking, it can be deduced from the data that the peak of dengue infection is in the late monsoon seasons, which is throughout October to February in Sabah. This period is also coinciding with the national school holidays during which time families travel to different parts of Malaysia to meet relatives or for leisure. This might help in further spreading dengue to different places as there is an association of human movements with an increase in dengue transmission [25].

All four dengue serotypes have been reported from Malaysia [26]. National-level data, i.e. cumulative data from the whole of Malaysia, showed that in 2013, DENV2 was predominant, followed by a shift to DENV1 after the second half of 2014 [27]. While in Sabah, the predominant serotypes in 2013 and 2014 were DENV-4 and DENV-1, respectively. Again, at the national level, DENV-1 continued to be predominant in 2015 and 2016, and DENV 2 in 2017 [6]. Interestingly, in 2015, DENV-2 was predominant in Sabah, and from 2016 up to 2018, DENV-3 became predominant.

Therefore, the predominant serotypes circulating in Sabah are different from the national level serotypes. This may be attributed to the fact that Sabah is approximately $1600 \mathrm{~km}$ from peninsular Malaysia and close to Sarawak and countries such as Indonesia, the Philippines, and Brunei. Although there were no published reports on the serotype distributions in Brunei and Sarawak, in Indonesia, the predominant serotype was DENV-3 in 2015 [28]. Similarly in Kalimantan, which is the closest Indonesian province to Sabah, DENV-3 was reported as the predominant DENV in 2015 to 2016 [29], which resembled Sabah's serotype dominance at the time. In the Philippines, the predominant serotype in 2015 was DENV-2 [30], which again was similar to Sabah.

The number of severe cases increased considerably in 2018 which was a 96\% increase from the previous year. It was also observed that many severe cases were from the east coast of Sabah, mainly Tawau, Lahad Datu, Semporna, and Sandakan. However, most dengue cases reported were from the western coast, mainly the district of Kota Kinabalu. Based on the results obtained from this study, we have identified that children infected with mixed serotypes and DENV-1 serotypes were significantly associated with severe dengue as compared to those infected with DENV-2, 3, and 4. Some studies have shown that there is a strong correlation between DENV-1 with severe outcomes when compared with DENV-2 and DENV-3 [6]. In this study, we identified that cases from the eastern coast of Sabah were significantly associated with severe dengue when compared to other parts of the state. A previous study also identified that the east coast of Sabah bears the brunt when it comes to severe dengue cases [18] similar to the findings of this study. This shows that these three factors can be incorporated into a predictive model for severe dengue. The case fatality rate (CFR) of dengue in Malaysia varied from 0.18 to $0.28 \%$ during 2013-2018 (http://idengue. arsm.gov.my/. Accessed 6 July 2020). For Sabah, the CFR in 2013 was $0.69 \%$; in 2014, it was decreased to $0.41 \%$; and in 2015 and 2016, it further decreased to $0.344 \%$ and $0.08 \%$, respectively. However, in 2017, the CFR increased to $0.31 \%$, and in 2018 , it was $0.85 \%$. Although the CFR of Sabah was higher than the national level, these levels were below $1 \%$ as targeted by the WHO.

Possibly, dengue has been around in Sabah for a long time as the vector has been known to be present in Sabah from as early as 1920 [31]. However, the increasing number of dengue cases has only started lately, and the reasons behind it are largely unknown. Dengue is known as an urban disease as it strives in urban surroundings [32], and since rapidly expanding urban populations [33] can be observed in Sabah, it is thought that urbanization might be a factor for an increased incidence of dengue. Sabah is rapidly gaining economic progress with the state GDP increasing from $2.7 \%$ in 2011 to $8.2 \%$ in 2017 [34] and experiencing rapid urbanization in the form of large physical growth of urban areas along with environmental changes leading to economic development [35]. The dynamic movement of people and the change in land use are mediators for human-mosquito interactions, which indirectly expands mosquito habitats [36]. These figures interestingly reflect the trend of increasing dengue cases from 2013 to 2018 in Sabah, indicating perhaps a correlation between both trends.

\section{Conclusions}

Dengue burden is high in Sabah, with increasing mortality especially in children, infection with mixed serotypes, and cases from the east coast being the biggest contributors to severe dengue. More extensive research needs to be conducted to identify the genomic makeup of these virulent serotypes and to identify how it contributes to the severity of dengue. Understanding this might open a new avenue of supportive care which can be given earlier to reduce the number of deaths from dengue. The phenomenon of the mixed serotype must be studied more extensively along with DENV-1. With added information, appropriate changes can be made, and better strategies can be adopted to reduce the mortality rate especially in the early detection of potentially severe dengue cases. These factors can hopefully be incorporated into a severe dengue predictive model to ensure early detection.

This supports the hypothesis that the virus strain and small genotypic changes may be important modifying factors for severity, and hence, phylogenetic analysis is 
important when interpreting serotype-specific data [14]. The early detection of circulating serotypes could be an important approach to prevent severe clinical outcomes during dengue outbreaks [15]. This is important not only for dengue-endemic countries but also from the clinical aspect in non-endemic countries. This can aid in the management of travelers infected with various dengue viruses circulating globally [14].

\section{Abbreviations}

NS-1: Non-structural protein 1; DENV: Dengue virus; PCR: Polymerase chain reaction; RNA: Ribonucleic acid; Cl: Confidence interval; OR: Odds ratio; MYR: Malaysian Ringgit; US\$: United States of America dollar; GDP: Gross domestic products; WHO: World Health Organization; RNA: Ribonucleic acid; PCR: Polymerase chain reaction

\section{Acknowledgements}

The authors would like to express their deepest gratitude to the staff of Kota Kinabalu Public Health Laboratory, Director of Sabah State Health Department, and lecturers of University Malaysia Sabah. The authors would also like to thank the Director General of Health, Malaysia, for his permission to publish this article.

\section{Authors' contributions}

NK contributed to the concept/design, data analysis/interpretation, critical revision of the article, and approval of the article. SSSAR contributed to data collection, statistics, data analysis, and approval of the article. JJ contributed to the sample collection, experiment management, data collection, and approval of the article. JJFD contributed to sample collection, experiment management, data collection, critical review of the article, and approval of the article. KTK contributed to the experiment management, data collection, and approval of the article. KA contributed to the concept/design, data collection, data interpretation, drafting the article, and approval of the article.

\section{Funding}

This project was partly funded by the Fundamental Research Grant Scheme for Research Acculturation of early career research (FRGS- Racer), grant number: RACER06-2019, and University Malaysia Sabah Postgraduate Grant (UMSGreat), grant number: GUG0368-1/2019.

\section{Availability of data and materials}

The datasets used and/or analyzed during the current study are available from JJFD, Kota Kinabalu Public Health Laboratory, on reasonable request.

\section{Ethics approval and consent to participate}

The study was registered, and ethical clearance obtained from the National Medical Research Register (NMRR-18-2869-41360). All data obtained in this study were saved in a password-protected computer that is only accessible to the researchers. The confidentiality of each patient is maintained as no identifiable individual information was recorded.

\section{Consent for publication}

Not applicable.

\section{Competing interests}

The authors declare that they have no competing interests.

\section{Author details}

${ }^{1}$ Department of Community and Family Medicine, Faculty of Medicine and Health Sciences, Universiti Malaysia Sabah, 88400 Kota Kinabalu, Sabah, Malaysia. ${ }^{2}$ Public Health Lab, Kota Kinabalu Public Health Laboratory, Sabah State Health Department, 88300 Kota Kinabalu, Sabah, Malaysia. ${ }^{3}$ Vector borne Unit, Sabah State Health Department, 88590 Kota Kinabalu, Sabah, Malaysia. ${ }^{4}$ Borneo Medical and Health Research Centre, Faculty of Medicine and Health Sciences, Universiti Malaysia Sabah, 88400 Kota Kinabalu, Sabah Malaysia. ${ }^{5}$ Department of Pathobiology and Medical Diagnostics, Faculty of Medicine and Health Sciences, Universiti Malaysia Sabah, Jalan UMS, 88400 Kota Kinabalu, Sabah, Malaysia.
Received: 15 May 2020 Accepted: 2 August 2020

Published online: 14 August 2020

\section{References}

1. L'Azou M, Assoukpa J, Fanouillere K, Plennevaux E, Bonaparte M, Bouckenooghe A, Frago C, Noriega F, Zambrano B, Ochiai RL, Guy B, Jackson N. Dengue seroprevalence: data from the clinical development of a tetravalent dengue vaccine in 14 countries (2005-2014). Trans R Soc Trop Med Hyg. 2018;112:158-68.

2. Murray NEA, Quam MB, Wilder-Smith A. Epidemiology of dengue: past, present and future prospects. Clin Epidemiol. 2013;5:299.

3. Campbell LP, Luther C, Moo-Llanes D, Ramsey JM, Danis-Lozano R, Peterson AT. Climate change influences on global distributions of dengue and chikungunya virus vectors. Philos Trans R Soc B. 2015;370:20140135.

4. Ajibola L-SA, Shohaimi S, Adam MB, Nadzir MNHM, Segun OE. Systematic review of knowledge, attitude, and practices regarding dengue in Malaysia. J Appl Pharmaceutical Sci. 2018:8:080-91.

5. Zanini F, Robinson ML, Croote D, Sahoo MK, Sanz AM, Ortiz-Lasso E, Albornoz LL, Rosso F, Montoya JG, Goo L, Pinsky BA, Quake SR, Einav S. Virus-inclusive single-cell RNA sequencing reveals the molecular signature of progression to severe dengue. Proc Natl Acad Sci U S A. 2018;115: E12363-E9.

6. Suppiah J, Ching S-M, Amin-Nordin S, Mat-Nor L-A, Ahmad-Najimudin N-A, Low GK-K, Abdul-Wahid M-Z, Thayan R, Chee H-Y. Clinical manifestations of dengue in relation to dengue serotype and genotype in Malaysia: a retrospective observational study. PLoS Negl Trop Dis. 2018;12:e0006817.

7. Lauer SA, Sakrejda K, Ray EL, Keegan LT, Bi Q, Suangtho P, Hinjoy S, lamsirithaworn S, Suthachana S, Laosiritaworn Y, Cummings DAT, Lessler J, Reich NG. Prospective forecasts of annual dengue hemorrhagic fever incidence in Thailand, 2010-2014. Proc Natl Acad Sci U S A. 2018;115: E2175-E82.

8. Mutsuddy P, Tahmina Jhora S, Shamsuzzaman AKM, Kaisar S, Khan MNA. Dengue situation in Bangladesh: an epidemiological shift in terms of morbidity and mortality. Can J Infect Dis Med Microbiol. 2019;2019:3576284.

9. Alera MT, Srikiatkhachorn A, Velasco JM, Tac-An IA, Lago CB, Clapham HE, Fernandez S, Levy JW, Thaisomboonsuk B, Klungthong C, Macareo LR, Nisalak A, Hermann L, Villa D, Yoon I-K. Incidence of dengue virus infection in adults and children in a prospective longitudinal cohort in the Philippines. PLoS Neg Trop Dis. 2016;10:e0004337-e.

10. Castonguay-Vanier J, Klitting R, Sengvilaipaseuth O, Piorkowski G, Baronti C, Sibounheuang B, Vongsouvath M, Chanthongthip A, Thongpaseuth S, Mayxay M, Phommasone K, Douangdala P, Inthalath S, Souvannasing P, Newton PN, de Lamballerie $X$, Dubot-Pérès A. Molecular epidemiology of dengue viruses in three provinces of Lao PDR, 2006-2010. PLoS Neg Trop Dis. 2018;12:e0006203.

11. Myat TW, Thu HM, Win HM, Than KS, Tun ZT, Aye KM, Zaw N, Aye KS, Thant KZ. Clinical profile and circulating dengue virus serotype among adults admitted to Yangon General Hospital during the 2015 dengue outbreak. OSIR J. 2017;10:8-13.

12. Bhatia R, Dash AP, Sunyoto T. Changing epidemiology of dengue in SouthEast Asia. WHO South-East Asia J Public Health. 2013;2(1):23.

13. Waman VP, Kolekar P, Ramtirthkar MR, Kale MM, Kulkarni-Kale U. Analysis of genotype diversity and evolution of Dengue virus serotype 2 using complete genomes. Peer J. 2016;4:e2326-e.

14. Yung C-F, Lee K-S, Thein T-L, Tan L-K, Gan VC, Wong JGX, Lye DC, Ng L-C, Leo Y-S. Dengue serotype-specific differences in clinical manifestation, laboratory parameters and risk of severe disease in adults, Singapore. Am J Trop Med Hyg. 2015;92:999-1005.

15. Najri NI, Mazlan Z, Jaimin JJ, Mohammad R, Mohd TAA, Hameed AA, Kumar $V$, Hoque MZ. AB084. The circulating serotypes of dengue in Sabah, Malaysian Borneo. Ann Transl Med. 2017;5(Suppl 2):AB084.

16. Department of Statistics Malaysia Official Portal 2019. Available from: https:// www.dosm.gov.my/v1/index.php?r=column/cone\&menu_id=dTZOK204 YXgrSDRtaEJyVmZ1R2h5dz09.

17. World Health O. Dengue guidelines for diagnosis, treatment, prevention and control: new edition. Geneva: World Health Organization; 2009.

18. Murphy A, Rajahram GS, Jilip J, Maluda M, William T, Hu W, Reid S, Devine GJ, Frentiu FD. Spatial and epidemiologic features of dengue in Sabah, Malaysia. BioRxiv. 2019;657031.

19. Rodriguez-Barraquer I, Salje H, Cummings DA. Dengue vaccine in regions of endemic disease. New Engl J Med. 2016:374:1388. 
20. Mia MS, Begum RA, Er AC, Pereira JJ. Assessing the cost burden of dengue infection to households in Seremban, Malaysia. Southeast Asian J Trop Med Public Health. 2016;47:1167-76.

21. Packierisamy PR, Ng C-W, Dahlui M, Inbaraj J, Balan VK, Halasa YA, Shepard DS. Cost of dengue vector control activities in Malaysia. Am J Trop Med Hyg. 2015;93:1020-7.

22. Chow V, Chan Y, Yong R, Lee K, Lim L, Chung Y, Lam-Phua S, Tan B. Monitoring of dengue viruses in field-caught Aedes aegypti and Aedes albopictus mosquitoes by a type-specific polymerase chain reaction and cycle sequencing. Am J Trop Med Hyg. 1998;58:578-86.

23. Chen $\mathrm{W}$-J. Dengue outbreaks and the geographic distribution of dengue vectors in Taiwan: a 20-year epidemiological analysis. Biom J. 2018;41:283-9.

24. Paupy C, Ollomo B, Kamgang B, Moutailler S, Rousset D, Demanou M, Hervé J, Leroy E, Simard F. Role of Ae. albopictus versus Ae. aegypti in dengue and chikungunya emergences in Central Africa: laboratory and field evidence. Vector Borne Zoonotic Dis. 2010;10:259-66.

25. Zellweger RM, Cano J, Mangeas M, Taglioni F, Mercier A, Despinoy M, Menkès CE, Dupont-Rouzeyrol M, Nikolay B, Teurlai M. Socioeconomic and environmental determinants of dengue transmission in an urban setting: an ecological study in Nouméa, New Caledonia, PLoS Negl Trop Dis 2017;11: e0005471.

26. Mustafa M, Rasotgi $V$, Jain S, Gupta V. Discovery of fifth serotype of dengue virus (DENV-5): a new public health dilemma in dengue control. Med J Armed Forces India. 2015;71(1):67-70.

27. Nani R. Dengue incidence and the prevention and control program in Malaysia; 2015.

28. Utama IMS, Lukman N, Sukmawati DD, Alisjahbana B, Alam A, Murniati D, Utama IMGDL, Puspitasari D, Kosasih H, Laksono I, Karyana M, Karyanti MR, Hapsari MMDEAH, Meutia N, Liang CJ, Wulan WN, Lau C-Y, Parwati KTM. Dengue viral infection in Indonesia: epidemiology, diagnostic challenges, and mutations from an observational cohort study. PLoS Negl Trop Dis. 2019;13:e0007785.

29. Sasmono RT, Kalalo LP, Trismiasih S, Denis D, Yohan B, Hayati RF, Haryanto S. Multiple introductions of dengue virus strains contribute to dengue outbreaks in East Kalimantan, Indonesia, in 2015-2016. Virol J. 2019;16:93.

30. Galarion MJ, Schwem B, Pangilinan C, dela Tonga A, Petronio-Santos JA, de los Reyes E, Destura R. Genotypic persistence of dengue virus in the Philippines. Infect Genet Evol. 2019;69:134-41.

31. King L, Hii F. A re-survey of Aedes aegypti and Aedes albopictus in Sabah, Malaysia. Buletin Penelitian Kesehatan. 1978;6(1 Mar).

32. Akhtar R, Gupta PT, Srivastava AK. Urbanization, urban heat island effects and dengue outbreak in Delhi. In: Akhtar R, editor. Climate Change and Human Health Scenario in South and Southeast Asia. Cham: Springer International Publishing; 2016. p. 99-111.

33. Chew $\mathrm{CH}$, Woon YL, Amin F, Adnan TH, Abdul Wahab AH, Ahmad ZE, Bujang MA, Abdul Hamid AM, Jamal R, Chen WS, Hor CP, Yeap L, Hoo LP, Goh PP, Lim TO. Rural-urban comparisons of dengue seroprevalence in Malaysia. BMC Public Health. 2016;16(1):824.

34. Kinabalu K. Strategy to build a transshipment port as a catalyst to achieving critical mass for Sabah s economic growth. International Business Res. 2019;12(7).

35. Heilig GK. World urbanization prospects: the 2011 revision. New York: United Nations, Department of Economic and Social Affairs (DESA), Population Division, Population Estimates and Projections Section; 2012. p. 14.

36. Carvajal TM, Ho HT, Hernandez LFT, Viacrusis KM, Amalin DM, Watanabe K. An ecological context toward understanding dengue disease dynamics in urban cities: a case study in Metropolitan Manila, Philippines. In: Watanabe T, Watanabe C, editors. Health in Ecological Perspectives in the Anthropocene. Singapore: Springer Singapore; 2019. p. 117-31.

\section{Publisher's Note}

Springer Nature remains neutral with regard to jurisdictional claims in published maps and institutional affiliations.

Ready to submit your research? Choose BMC and benefit from:

- fast, convenient online submission

- thorough peer review by experienced researchers in your field

- rapid publication on acceptance

- support for research data, including large and complex data types

- gold Open Access which fosters wider collaboration and increased citations

- maximum visibility for your research: over $100 \mathrm{M}$ website views per year

At BMC, research is always in progress.

Learn more biomedcentral.com/submissions 